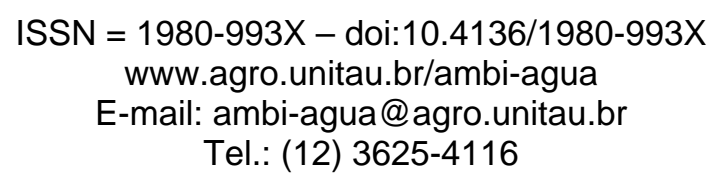

\title{
Efeitos do pH, acidez e alcalinidade na microbiota de um reator anaeróbio de manta de lodo (UASB) tratando efluentes de suinocultura
}

(doi:10.4136/ambi-agua.109)

\author{
Erlon Lopes Pereira; Cláudio Milton Montenegro Campos; Fabrício Moterani \\ Universidade Federal de Lavras - UFLA \\ E-mail: erlonlopes@gmail.com; cmmcampos@gmail.com; fabricio.moterani@gmail.com
}

\section{RESUMO}

Os processos anaeróbios de tratamento de esgoto vêm sendo frequentemente utilizados com a finalidade de otimizar sistemas de tratamento das águas residuárias, entre estes, um dos mais difundidos é o do reator anaeróbio de manta de lodo. Neste, procura-se acelerar o processo da digestão criando-se condições favoráveis para a atividade dos micro-organismos que degradam a matéria orgânica. O objetivo deste trabalho foi avaliar o efeito da temperatura, $\mathrm{pH}$, acidez e alcalinidade sobre o consórcio microbiano de um reator UASB, observando-se ainda a morfologia do lodo por meio de análises de microscopia eletrônica de varredura (MEV), a fim de conhecer as melhores respostas do consórcio bacteriano em função de fatores de ambiência limitantes. O lodo operou sob temperature, variando $19^{0} \mathrm{C}$ e $21^{\circ} \mathrm{C}$. A concentração máxima de ácidos graxos voláteis foi de $100 \mathrm{mg} \mathrm{L}^{-1}$. A carga orgânica

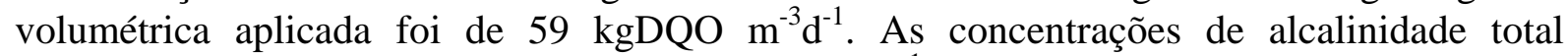
apresentaram valores entre 2500 e $5550 \mathrm{mgCaCO}_{3} \mathrm{~L}^{-1}$ e o valor do $\mathrm{pH}$ médio do lodo foi de 7,28. Sob as referidas circunstâncias operacionais, foi observado o desenvolvimento de uma biomassa granular bem aclimatizada, composta em sua maioria por bactérias filamentosas.

Palavras-chave: arqueias metanogênicas; microscopia eletrônica de varredura; UASB.

\section{Effects of pH, acidity and alkalinity on the microbiota activity of an anaerobic sludge blanket reactor (UASB) treating pigmanure effluents}

\section{ABSTRACT}

The anaerobic processes used for treating wastewater have been often applied mainly for optimizing treatment systems. Among many of these systems, the UASB is one of the most successfully used. This type of reactor presents a good condition for microorganisms development, and therefore, for organic matter degradation. As a result, the goal of this research was to evaluate the effect of parameters, such as: temperature, $\mathrm{pH}$, acidity and alkalinity on the microorganisms consortia, acclimatized in an UASB reactor, and simultaneously, observing the sludge morphology through a scanning electronic microscopy (SEM), in order to identify the response of the bacteria consortia under this environmental circumstances. The biomass operated under a mesophilic temperature, varying from $19^{\circ} \mathrm{C}$ to $21^{0} \mathrm{C}$. The maximum concentration of volatile acids was $100 \mathrm{mg} \mathrm{L}^{-1}$, and the volumetric

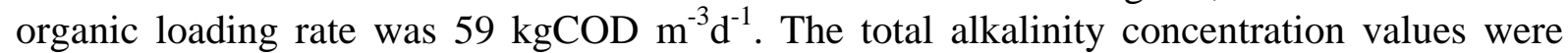
between 2500 and $5550 \mathrm{mgCaCO}_{3} \mathrm{~L}^{-1}$. The average $\mathrm{pH}$ value of the sludge was 7.3. Under these conditions it was observed the development of a well acclimatized granular biomass, composed mainly of filamentous bacteria.

Keywords: archeas methanogenic; scanning electronic microscopy; UASB. 
PEREIRA, E. L.; CAMPOS, C. M. M.; MOTERANI, F. Efeitos do pH, acidez e alcalinidade na microbiota de um reator anaeróbio de manta de lodo (UASB) tratando efluentes de suinocultura. Ambi-Agua, Taubaté, v. 4, n. 3, p. 157-168, 2009. (doi:10.4136/ambi-agua.109)

\section{INTRODUÇÃO}

A criação intensiva de suínos tem causado grandes problemas ambientais em algumas regiões do Brasil, devido às altas concentrações de matéria orgânica e nutrientes dos seus dejetos que, quando não são corretamente manejados e tratados, podem causar impactos negativos sobre a biota do solo e da água (Fernandes e Oliveira, 2006).

A consciência de que a adequação dos resíduos produzidos pelas diferentes atividades agropecuárias é de vital importância para a saúde pública e para o combate à poluição, tem levado ao desenvolvimento de sistemas de tratamento que combinem alta eficiência e baixos custos de operação e construção (Steil et al., 2002).

Os processos anaeróbios na decomposição dos esgotos vêm sendo frequentemente utilizados com a finalidade de otimizar sistemas de tratamento, entre estes, um dos mais difundidos é o reator UASB (Upflow Anaerobic Sludge Blanket Reator), também conhecido como RAMAL (Reator Anaeróbio de Manta de Lodo).

O reator UASB foi desenvolvido na década de 70 por Gatze Lettinga da Universidade de Wageningen, Holanda. Tem sido amplamente estudada a sua vantagem de combinar construção e operação simplificadas e com capacidade de acomodar elevadas cargas orgânicas e hidráulicas. Sua configuração é baseada no regime hidráulico e na incorporação de um dispositivo interno de separação trifásico (sólido/gás/líquido), dispensando o uso de meio suporte para o crescimento da biomassa (Metcalf e Eddy, 2003). Isso favorece o desenvolvimento e retenção de uma biomassa concentrada e altamente ativa, na forma de flocos densos ou mesmo de lodo granulado (Lourenço e Campos, 2009). O perfil de sólidos (lodo) no reator varia de muito denso com partículas granulares de elevada capacidade de sedimentação, que se situam próximas ao fundo, denominado leito de lodo, até um lodo mais disperso e leve, próximo ao topo do reator conhecido como manta de lodo (Campos et al., 2005b).

Nos sistemas de tratamento biológico, as bactérias são os grupos predominantes da biomassa e, portanto, os de maior importância. São organismos unicelulares, não possuem carioteca (membrana nuclear), e o núcleo fica difundido no citoplasma da célula. Esses microorganismos podem ser encontrados isolados ou agregados, formando colônias com características, filamentosas e/ou granulares. A morfologia destas bactérias pode variar em diversas formas e as mais encontradas são cocos e bastonetes (Neves, 2004).

Dentro do reino monera, as archeas metanogênicas compõe um grupo importante no tratamento biológico, pois são microrganismos estritamente anaeróbios podendo ser encontrados em solos alagados, sedimentos de lagos, pântanos e no trato gastrointestinal de animais e possuem capacidade de estabilizar a matéria orgânica transformando-a em gás metano.

O tamanho dessas bactérias varia conforme o grupo, podendo ter de 0,25 a $0,5 \mu \mathrm{m}$, e o crescimento é profundamente afetado pela temperatura, acidez, alcalinidade e pH (Campos et al., 2005c).

A temperatura determina em parte, a velocidade de crescimento e, consequentemente, a densidade de micro-organismos da biomassa. A temperatura ótima de crescimento é aquela que possibilita o mais rápido crescimento, durante o menor período de tempo. Cada espécie cresce sob temperaturas situadas em faixas características, sendo classificados nos grupos: psicrofílicas, mesofílicas e termofílicas.

Quanto à acidez e à alcalinidade são parâmetros de extrema importância para a digestão anaeróbia. Os ácidos graxos voláteis devem estar em equilíbrio com a alcalinidade do sistema. A inibição do processo anaeróbio por ácidos graxos voláteis está associada ao $\mathrm{pH}$. Baixos valores de $\mathrm{pH}$ estão geralmente relacionados a altas concentrações de ácidos graxos voláteis, e, consequentemente, a falência do processo (Kus e Wismann, 1995). Para a grande maioria 
das bactérias, o pH ótimo de crescimento se localiza entre 6,5 e 7,5. As variações máximas e mínimas, para a maior parte delas, estão entre $\mathrm{pH} 4$ e 9. Porém, se cultivadas em meio ajustado a um $\mathrm{pH}$ determinado, é provável que esse $\mathrm{pH}$ se altere, como resultado dos metabólicos produzidos, que podem ser tanto ácidos como alcalinos (Campos et al., 2006).

Nos processos de tratamento anaeróbio, procura-se acelerar as reações de digestão da matéria orgânica, criando-se condições favoráveis para crescimento e manutenção de microorganismos no reator (Campos et al., 2005a). Essas condições se relacionam tanto ao projeto do sistema de tratamento quanto às suas condições operacionais. Em relação ao projeto de sistemas de tratamento, é preciso garantir que haja grande quantidade de micro-organismos ativos atuando e que ocorra um contato intenso entre o substrato orgânico, presente no líquido, e a massa microbiana no sistema.

Portanto, o objetivo deste trabalho foi avaliar o efeito da temperatura, $\mathrm{pH}$, acidez e alcalinidade no consórcio microbiano de um reator UASB, observando sua morfologia por meio de análises de microscopia eletrônica de varredura (MEV), avaliando assim o desenvolvimento da biomassa em função da ambiência do meio líquido no reator.

\section{MATERIAL E MÉTODOS}

O reator UASB foi construído em alvenaria argamassada, impermeabilizada com Sika Top e revestida com manta asfáltica, todavia, a fim de se melhorar e se prevenir qualquer corrosão, posteriormente a unidade foi revestida com fibra de vidro. O volume do reator possuía $3,82 \mathrm{~m}^{3}$ e área $1,78 \mathrm{~m}^{2}$.

O separador trifásico do reator UASB foi construído utilizando-se meia manilha de concreto vibrado, com formato semicircular e diâmetro de $0,50 \mathrm{~m}$. Deste o biogás produzido era conduzido por meio de tubos PVC de 1/2” ao equalizador de pressão e, posteriormente, medido e queimado. O separador trifásico exercia também a função de um defletor de sólidos. Quando da ascensão de partículas sólidas (lodo) junto com bolhas de biogás, o choque destas com as paredes do separador trifásico fazia com que se separassem, obrigando assim, os sólidos a retornarem, por sedimentação, para o fundo do reator. Esse processo de retenção de sólidos foi fundamental para a formação da manta de lodo, aumentando a eficiência operacional. Para a realização da amostragem do perfil do lodo, foram instalados na parede lateral do reator, cinco amostradores distribuídos de maneira uniforme ao longo da altura deste.

\subsection{Partida (start-up)}

A partida do sistema foi dada sem inoculação da biomassa, utilizando-se parâmetros de sedimentação descritos em Costa (2007). Nesta pesquisa nivelou-se o lodo UASB deixando-o na altura do último amostrador, a 1,05 metros do fundo do reator. Esse processo foi importante para se conhecer o volume inicial do lodo.

Para controle do tamponamento do meio, crescimento do lodo e eficiência de remoção no reator foram analisados os parâmetros apresentados no Quadro 1. 
PEREIRA, E. L.; CAMPOS, C. M. M.; MOTERANI, F. Efeitos do pH, acidez e alcalinidade na microbiota de um reator anaeróbio de manta de lodo (UASB) tratando efluentes de suinocultura. Ambi-Agua, Taubaté, v. 4, n. 3, p. 157-168, 2009. (doi:10.4136/ambi-agua.109)

\subsection{Monitoramento físico-químico e operacional}

Quadro 1. Parâmetros, frequência e bibliografia de referência para as análises físico-químicas realizadas no lodo e no efluente.

\begin{tabular}{|c|c|c|}
\hline $\begin{array}{c}\text { Parâmetros } \\
\text { Físico-químicos }\end{array}$ & Frequência & Referência Bibliográfica \\
\hline $\mathrm{pH}$ & $2 \times$ semana & APHA, AWWA, WPCF (1998) \\
\hline $\begin{array}{c}\text { Alcalinidade total, parcial } \\
\text { e intermediária }\end{array}$ & 2 x semana & RIPLEY et al. (1986) e JENKINS et. al \\
\hline $\begin{array}{c}\text { Demanda Química de } \\
\text { Oxigênio (DQO) total, } \\
\text { filtrada }\end{array}$ & $2 \times$ semana & $\begin{array}{c}\text { APHA, AWWA, WPCF (1998), (método da } \\
\text { digestão com refluxo fechado). A filtração } \\
\text { foi feita em papel de filtro com porosidade } \\
25 \mu m\end{array}$ \\
\hline Sólidos Totais do lodo & Tabela 1 & APHA, AWWA, WPCF (1998) \\
\hline Acidez total & 2 x semana & método potenciométrico com NaOH 0,02 N \\
\hline
\end{tabular}

Os parâmetros operacionais avaliados foram: vazão (método gravimétrico) sempre durante a coleta do efluente que foi feita 2 vezes na semana, tempo de detenção hidráulica (TDH); carga hidráulica (CH); carga orgânica volumétrica (COV); carga orgânica biológica (COB) e medição da produção de biogás. As temperaturas ambientais máximas, mínimas e médias, bem como da umidade local foram medidas utilizando-se um termo-higrômetro marca Inconterm, instalado ao lado do reator UASB. As leituras foram realizadas diariamente, por volta das $8 \mathrm{~h}$ da manhã. A medição das temperaturas do lodo e efluente foi realizada por meio de um termômetro de mercúrio da marca Inconterm. As temperaturas eram medidas após a coleta das respectivas amostras.

\subsection{Microscopia Eletrônica de Varredura (MEV)}

As amostras dos cinco amostradores do reator UASB foram preparadas para observação em microscopia eletrônica de varredura (MEV), seguindo a seguinte metodologia: As amostras $(0,5 \mathrm{~mL})$ do lodo eram depositadas sobre lamínulas de $1 \mathrm{~mm}$ de diâmetro alojadas dentro de placas de Petri onde eram submersas em solução fixadora de Karnovisky modificado (glutaraldeído 2,5\%, formoldeído 2,5\% em tampão cacodilato 0,05 M com pH de 7,2 e $\mathrm{CaCl}_{2}$ 0,001 M) por 24 horas (tempo de secagem do fixador). Posteriormente, acrescentavam-se, em ambiente protegido (capela), 4 gotas de solução tetróxido de ósmio $\left(\mathrm{OsO}_{4}\right)$ a $1 \%$ (para pós-fixação), permanecendo por 4 horas em temperatura ambiente. As placas de Petri eram então lavadas por três vezes em água destilada e, posteriormente, levadas para o dessecador onde ficavam por 24 horas até a completa secagem. Após a secagem, as amostras eram montadas em stubs com aproximadamente $12 \mathrm{~mm}$ de diâmetro, e transferidas para a cobertura de ouro (sputtering) em aparelho da marca BALZERS, modelo SCD 050. Essa cobertura era necessária para aumentar a condutividade da amostra aos elétrons produzidos no filamento de tungstênio. As amostras foram observadas em microscópio eletrônico de varredura da marca LEO modelo EVO 40 e analisadas pelo software LEOUIF.

\section{RESULTADOS E DISCUSSÃO}

\subsection{Condições ambientais}

As faixas de temperaturas ambientais mínimas, médias e máximas registradas pelo termo-higrômetro do reator, foram: $14^{0} \mathrm{C}, 22^{\circ} \mathrm{C}, 30^{\circ} \mathrm{C}$, respectivamente, e as umidades relativas mínimas médias e máximas foram: 31\%, $66 \%$ e $94 \%$, respectivamente. O efluente operou em temperatura na faixa de $18^{0} \mathrm{C}$ a $24^{\circ} \mathrm{C}$. O lodo operou na faixa de $19^{0} \mathrm{C}$ a $21^{0} \mathrm{C}$. 
PEREIRA, E. L.; CAMPOS, C. M. M.; MOTERANI, F. Efeitos do pH, acidez e alcalinidade na microbiota de um reator anaeróbio de manta de lodo (UASB) tratando efluentes de suinocultura. Ambi-Agua, Taubaté, v. 4, n. 3, p. 157-168, 2009. (doi:10.4136/ambi-agua.109)

Considerou-se a temperatura do lodo devido a sua maior influência sobre os aspectos microbiológicos. Pode-se afirmar assim que as bactérias operaram em faixa mesofílica.

\subsection{Relações entre a Carga Orgânica Volumétrica (COV), Carga Orgânica Biológica e Acidez}

A afinidade pelo substrato tem papel importante no reator UASB e existe uma relação ecológica entre as arqueias metanogênicas acetoclásticas. A mais comum é a bactéria do gênero Metanosaeta, que apresenta uma taxa de crescimento maior por possuir uma elevada afinidade pelo substrato (constante de saturação), em que o Ks $=0,30 \mathrm{mM}$. Já as arqueias metanogênicas acetoclásticas, Metanosarcinas, cujo $\mathrm{Ks}=5,0 \mathrm{mM}$, possuem taxa de crescimento ainda mais elevada. Quanto menor a concentração de substrato menor a taxa de crescimento. Sendo assim, a Metanosarcina normalmente é a bactéria dominante quando o reator apresenta grande quantidade de ácidos graxos voláteis (Zegers, 1987). As bactérias fermentativas acidificam o substrato em uma velocidade oito vezes mais rápida do que as arqueias metanogênicas (metanosaeta) consomem os ácidos graxos voláteis (acidez). Se a carga de matéria orgânica no reator (COB), exceder a capacidade metanogênica, ocorrerá uma acumulação de ácidos graxos voláteis na unidade, com isso o pH diminuirá e, em conseqüência, esses ácidos poderão se tornar tóxicos ao consórcio bacteriano (Zegers, 1987).

De acordo com Chernicharo (2007), a carga orgânica biológica depende da atividade metanogênica do lodo (AME), sendo esta limitante para aplicação da COB que não afete a estabilidade do sistema. Oliveira et al. (1997), avaliando reatores UASB que tratavam efluentes de suinocultura, operaram com COB entre 0,13 a 0,24 kgDQOtotal kg-1STV d-1 e observou estabilidade no sistema. Steil et al. (2002) encontraram maiores valores de AME com COB menores que 0,25 kgDQOtotal kg-1STV d-1. Santana e Oliveira (2005), avaliando lodo de reatores UASB tratando efluentes de suinocultura, determinaram COB limites de 0,3kgDQOtotal kg-1STV d-1. Pode-se observar que os valores de COB bruta aplicadas ao reator UASB (Tabela 1), foram abaixo dos valores limites encontrados nas várias pesquisas realizadas. Portanto, conclui-se que o consórcio microbiano não foi prejudicado pela COB aplicada.

Tabela 1. Caracterização física do lodo e COB submetida ao reator.

\begin{tabular}{ccccccccc}
\hline $\begin{array}{c}\text { Dias de } \\
\text { pesquisa }\end{array}$ & $\begin{array}{c}\text { STV do } \\
\text { lodo }\end{array}$ & $\begin{array}{c}\text { DQO } \\
\text { bruta }\end{array}$ & $\begin{array}{c}\text { DQO } \\
\text { filtrada }\end{array}$ & $\begin{array}{c}\text { Q } \\
\text { média }\end{array}$ & $\begin{array}{c}\text { COB } \\
\text { bruta }\end{array}$ & $\begin{array}{c}\text { COB } \\
\text { filtrada }\end{array}$ & TDH & CH \\
\hline $24^{\circ}$ & 192,034 & 8,48 & 1,664 & 7,7 & 0,179 & 0,0351 & 11,9 & 2,02 \\
$71^{\circ}$ & 229,194 & 4,83 & 1,724 & 7,5 & 0,083 & 0,0297 & 12,2 & 1,97 \\
$87^{\circ}$ & 252,452 & 7,86 & 1,45 & 8,1 & 0,133 & 0,0245 & 11,3 & 2,12 \\
$114^{\circ}$ & 249,485 & 5,87 & 1,463 & 8,4 & 0,104 & 0,0259 & 10,9 & 2,20 \\
\hline
\end{tabular}

STV do lodo $\left(\mathrm{kg} \mathrm{m}^{-3}\right)$, DQO bruta e filtrada $\left(\mathrm{kg} \mathrm{m}^{-3}\right), \mathrm{Q}\left(\mathrm{m}^{3} \mathrm{~d}^{-1}\right)$, COB $\left({\mathrm{kgDQO} \mathrm{kg}^{-1} \mathrm{STV} \mathrm{d}}^{-1}\right)$, TDH (horas), CH $\left(\mathrm{m}^{3} \mathrm{~m}^{-3} \mathrm{~d}^{-1}\right)$.

Em análises comparativas entre as Figuras 1 e 2, observa-se que a COV aplicada ao reator, resultou em concentrações de ácidos graxos voláteis menores que a concentração limite para inibição da atividade metanogênica, referente a $150 \mathrm{mg} \mathrm{L}^{-1}$. De acordo com Chernicharo (2007), para projetos de estações em escala plena, tem sido via de regra adotar valores de COV inferiores a $15 \mathrm{kgDQO}_{\text {total }} \mathrm{m}^{-3} \mathrm{~d}^{-1}$, embora cargas orgânicas extremamente elevadas, na ordem de $45 \mathrm{kgDQO}_{\text {total }} \mathrm{m}^{-3} \mathrm{~d}^{-1}$, tenham sido aplicadas com sucesso em instalações piloto. No presente experimento, submetemos o reator a cargas máximas de 59 $\mathrm{kgDQO}_{\text {total }} \mathrm{m}^{-3} \mathrm{~d}^{-1}$, obtendo concentrações de ácidos voláteis totais máximas de $100 \mathrm{mg} \mathrm{L}^{-1}$. 


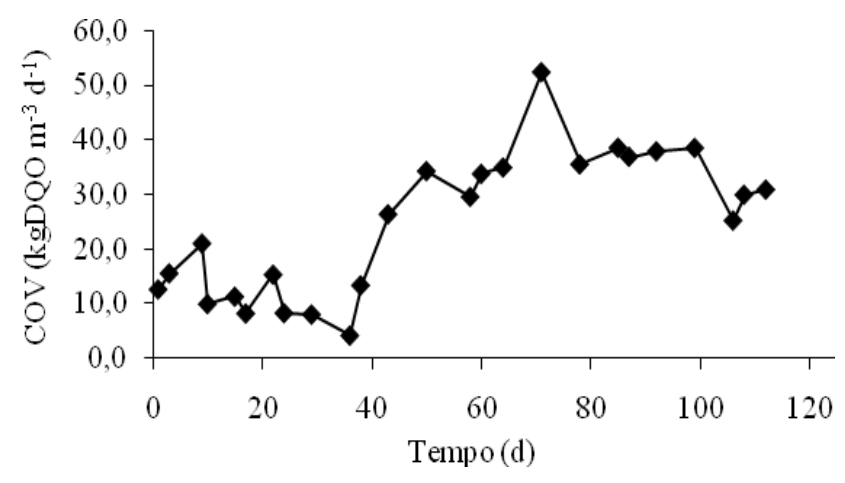

Figura 1. Comportamento da Carga Orgânica Volumétrica no reator UASB durante a pesquisa.

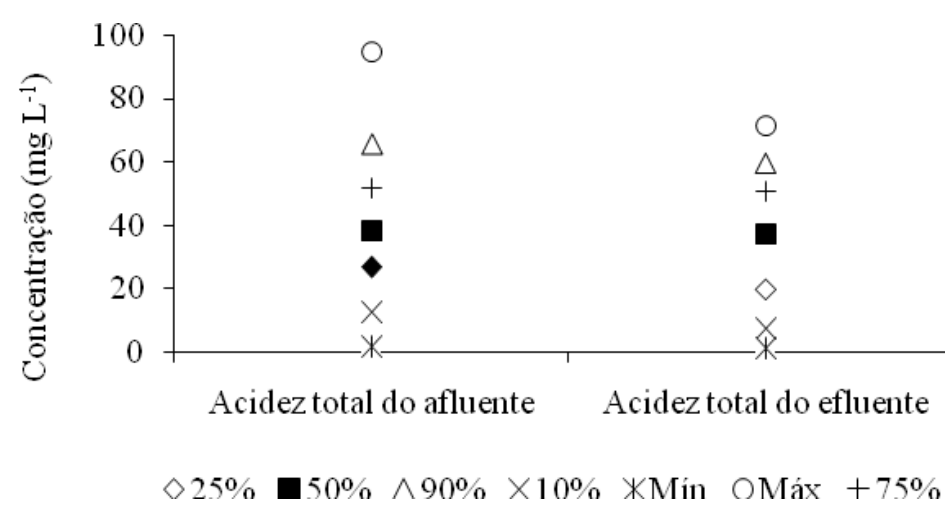

Figura 2. Gráfico de Box-Whisker para a concentração de ácidos graxos voláteis no reator UASB.

\subsection{Resposta microbiológica}

As morfologias observadas nos grânulos da manta de lodo do reator UASB foram praticamente semelhantes no início e no final do experimento e houve predominância de morfologias de bactérias semelhantes à metanosarcinas, devido às concentrações de ácidos graxos voláteis atingirem valores altos, porém abaixo do valor limite (Figura 4). Entretanto, encontraram-se também bactérias semelhantes à metanosaeta (Figura 3), demonstrando o equilíbrio ecológico entre as archeas metanogênicas, propiciando uma biomassa diversificada. Devido a elevadas frações de sólidos suspensos, da elevada velocidade ascensional do líquido e das variações de outros parâmetros operacionais, tudo isso pode ter levado com que o reator apresentasse partículas de lodo com estrutura densa e granular, conforme pode ser observado na Figura 5. 
PEREIRA, E. L.; CAMPOS, C. M. M.; MOTERANI, F. Efeitos do pH, acidez e alcalinidade na microbiota de um reator anaeróbio de manta de lodo (UASB) tratando efluentes de suinocultura. Ambi-Agua, Taubaté, v. 4, n. 3, p. 157-168, 2009. (doi:10.4136/ambi-agua.109)

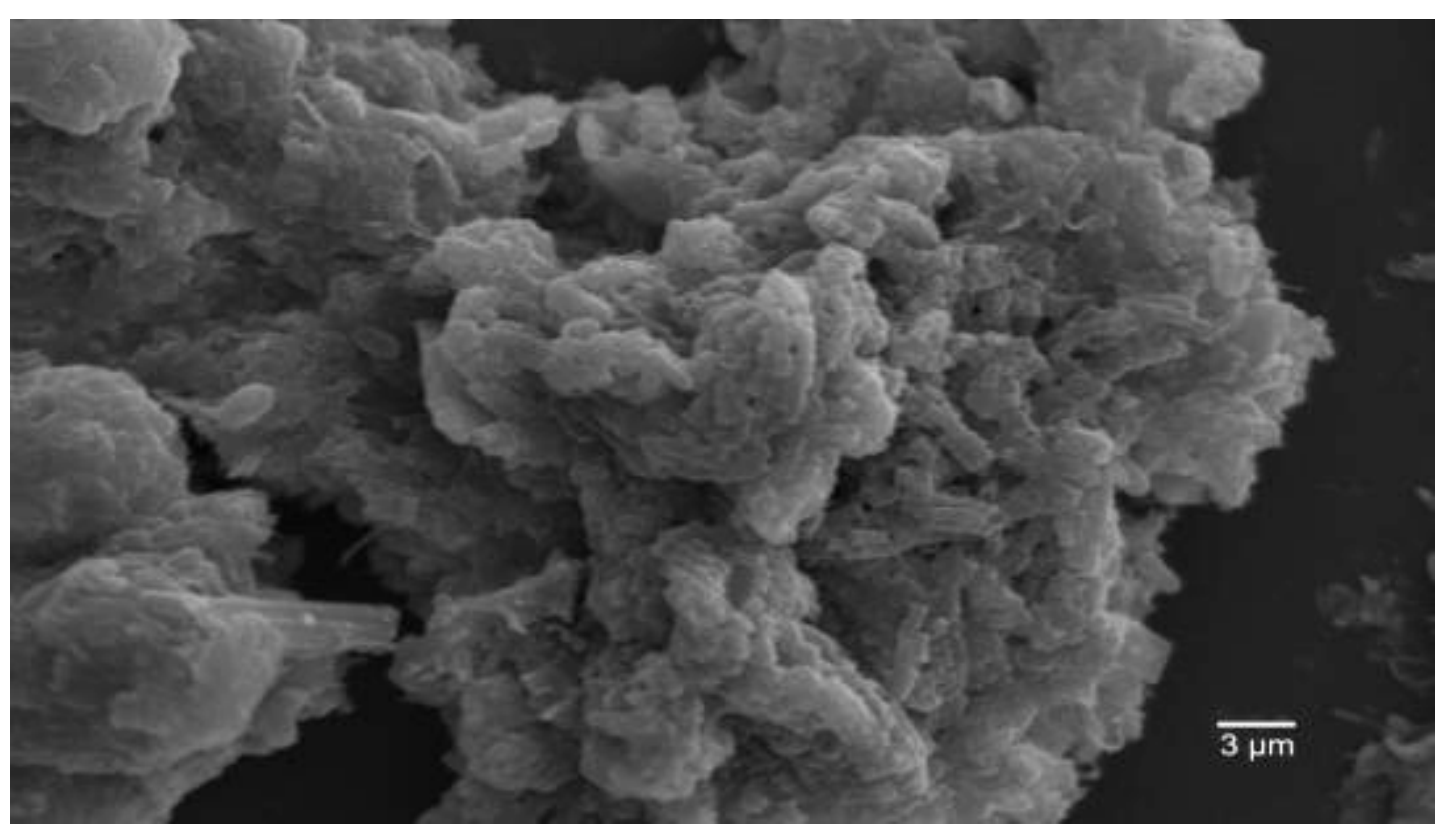

Figura 3. Bactérias Filamentosas no lodo do Reator UASB (MEV).

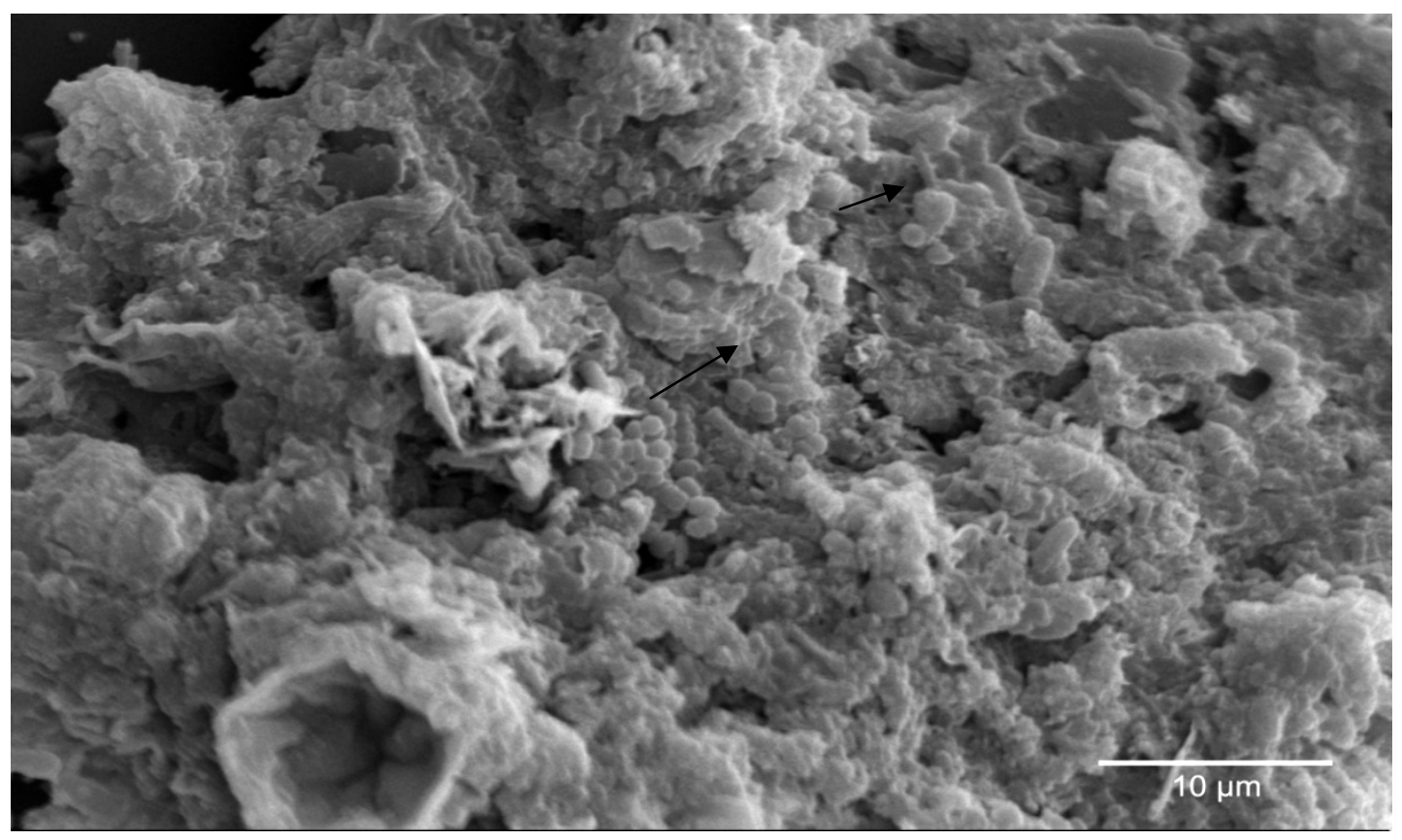

Figura 4. Foto do grânulo do lodo do Reator UASB em maior aumento. Detalhe para o centro da foto formação de cocos aderidos ao grânulo. 


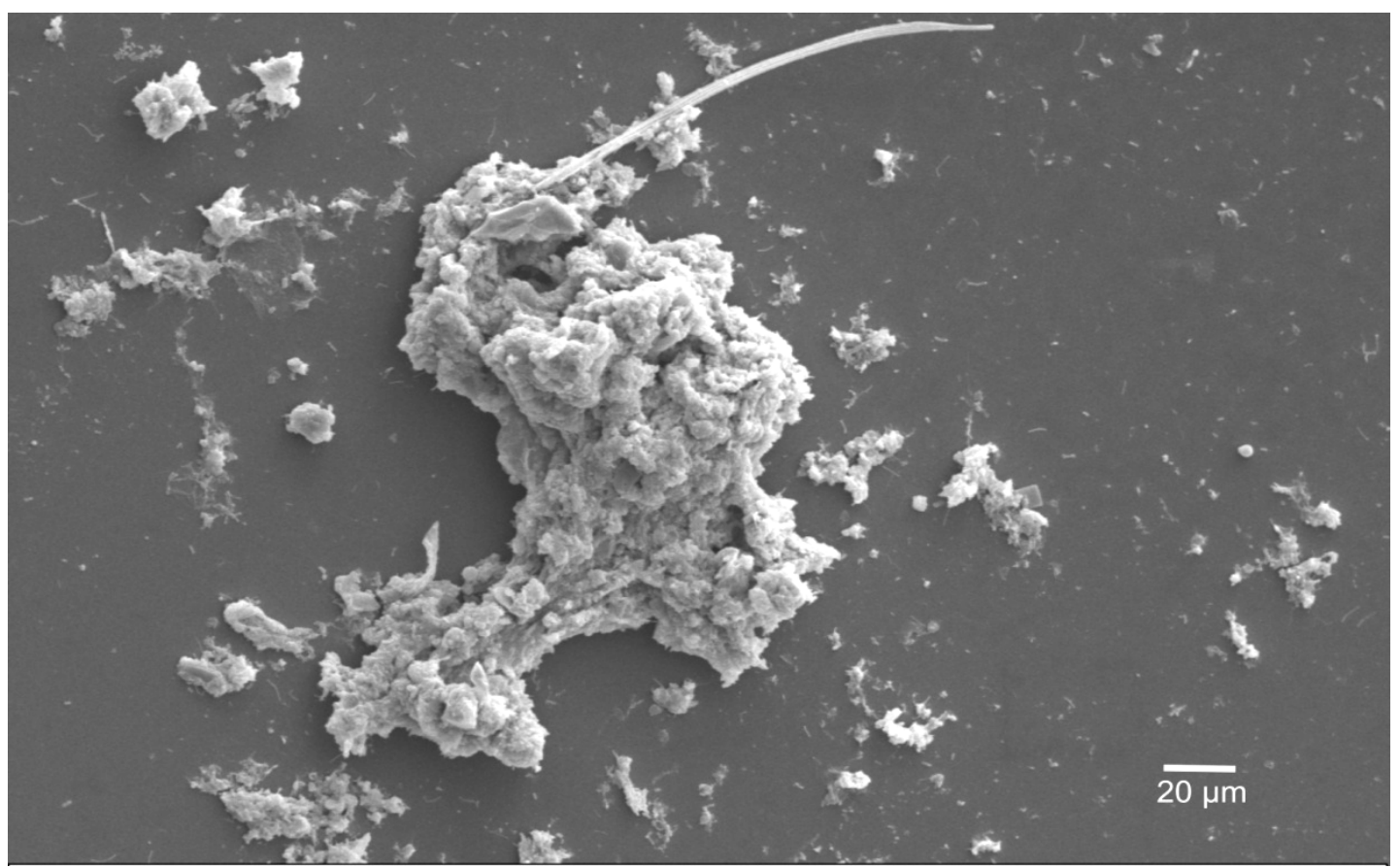

Figura 5. Grânulo do lodo do Reator UASB (MEV).

\subsection{O efeito do AGV no pH}

Os ácidos graxos voláteis são tóxicos para as bactérias metanogênicas somente em sua forma não ionizada. Os valores de $\mathrm{pH}$ geralmente desejados em um tratamento anaeróbio está entre 6,7 e 8,0, em que os ácidos orgânicos estão em sua maioria (>99\%) em sua forma ionizada (não tóxica). Quando o $\mathrm{pH}$ diminui, os ácidos graxos voláteis estão menos desassociados (tóxicos). A um pH em torno de 5, os ácidos graxos voláteis estarão desassociados em $50 \%$ aproximadamente. Uma concentração de ácido acético e ácido propiônico na forma desassociada de 16 e $6 \mathrm{mgDQO} \mathrm{L}^{-1}$, respectivamente, causa $50 \%$ de inibição da atividade metanogênica (Zegers, 1987). A presença de ácidos graxos voláteis em sua forma não ionizada em um pH inferior a 6, pode causar uma severa inibição das bactérias metanogênicas. Por outra parte, as bactérias fermentativas são mais ativas a um pH em torno de 4,5. Quando a capacidade metanogênica está continuamente sobrecarregada e não se estabiliza, os ácidos graxos presentes no reator farão com que a unidade de tratamento fique acidificada ( $\mathrm{pH}$ entre 4,0 a 5). Recomenda-se então manter o reator em um intervalo de $\mathrm{pH}$ entre 7,0 e 7,5. Os intervalos de $\mathrm{pH}$ encontrados para o afluente e efluente do reator UASB foram 6,8 a 7, 9 e 7,2 a 8,8, respectivamente, isso demonstra que os ácidos graxos voláteis estavam na sua grande maioria de forma ionizada, não tóxicos para às bactérias metanogênicas. O lodo retirado nos amostradores $1,2,3,4$ e 5, apresentaram pH entre 7,2 e 7,$4 ; 7,3$ e 7,4; 7,3 e 7,4; 7,3 e 7,3 e 7,4 e 7,4; respectivamente. Portanto o reator UASB demonstrou boas condições de tamponamento, o que de acordo com Campos et al. (2006), é um fator muito importante, principalmente quando se leva em consideração o custo de manutenção, pois a adição de substâncias químicas para tamponamento oneraria o processo.

\subsection{Alcalinidades total, parcial e intermediária}

Segundo Grady e Lim (1980) para a maioria dos casos práticos, uma alcalinidade total entre 2500 e $5000 \mathrm{mgCaCO} \mathrm{L}_{3} \mathrm{~L}^{-1}$ é suficiente para se obter um adequado poder tampão no sistema. Como pode ser observado no gráfico Box-Whisker (Figuras 6 e 7), mais de $90 \%$ dos valores de alcalinidade total do afluente e efluente ficaram dentro do intervalo proposto, colaborando para otimização do processo de metanificação. 
Entretanto, Ripley et al. (1986) citado por Chernicharo (2007), propoem a determinação separada da alcalinidade bicarbonato (alcalinidade parcial - AP) e alcalinidade ácidos voláteis (alcalinidade intermediária - AI). Essa determinação é importante no que se refere ao significado da relação AI/AP. De acordo com Ripley et al. (1986), valores da relação AI/AP superiores a 0,3 indicam a ocorrência de distúrbios no processo de digestão anaeróbia. Chernicharo (2007) escreve que devido as particularidades de cada efluente, mesmo com relações AI/AP superiores a 0,3, alguns reatores não demonstram distúrbios no processo. As relações AI/AP encontradas na presente pesquisa ultrapassaram o valor 0,3 proposto por Ripley (1986), porém, gradualmente os valores diminuíram ao longo do tempo até atingirem valores estáveis no fim da pesquisa. Essa tendência de estabilidade ocorreu devido à aclimatização da biomassa. Observou-se ainda que os valores apresentados no afluente foram menores que no efluente devido ao aumento da concentração de alcalinidade dos ácidos voláteis ao passar pelo reator (Figura 8).

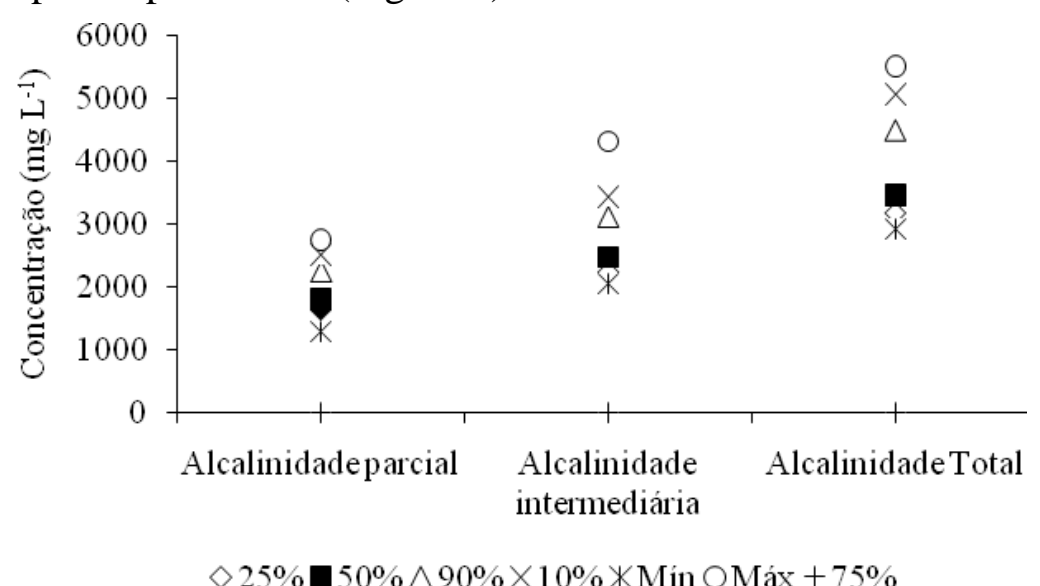

Figura 6. Gráfico de Box-Whisker para alcalinidades do afluente do reator UASB.

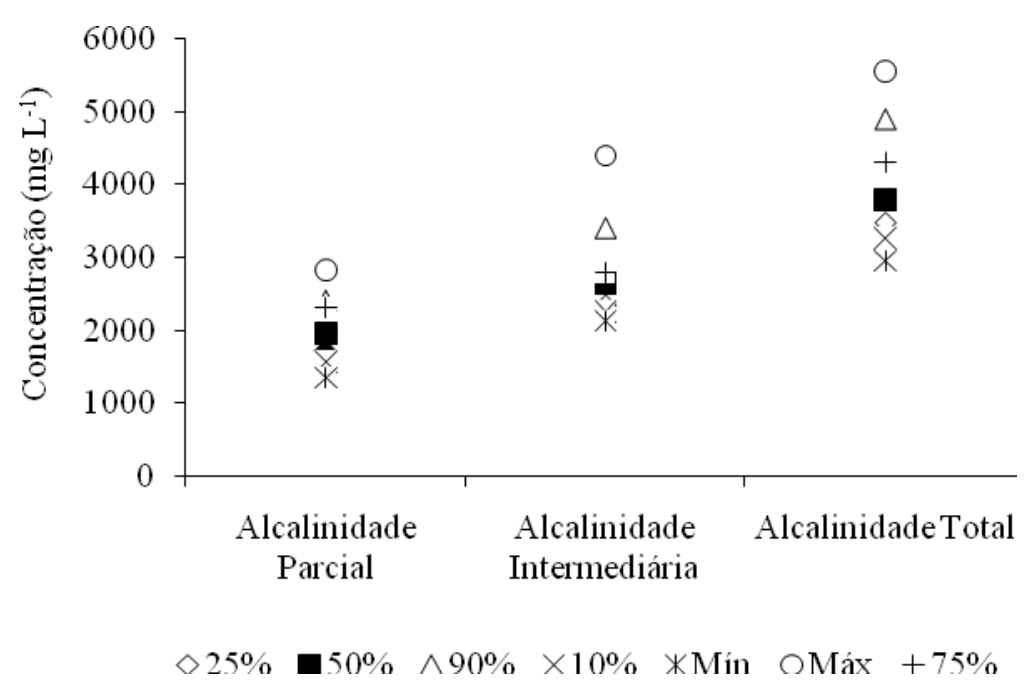

Figura 7. Gráfico de Box-Whisker para as alcalinidades do efluente do reator UASB. 


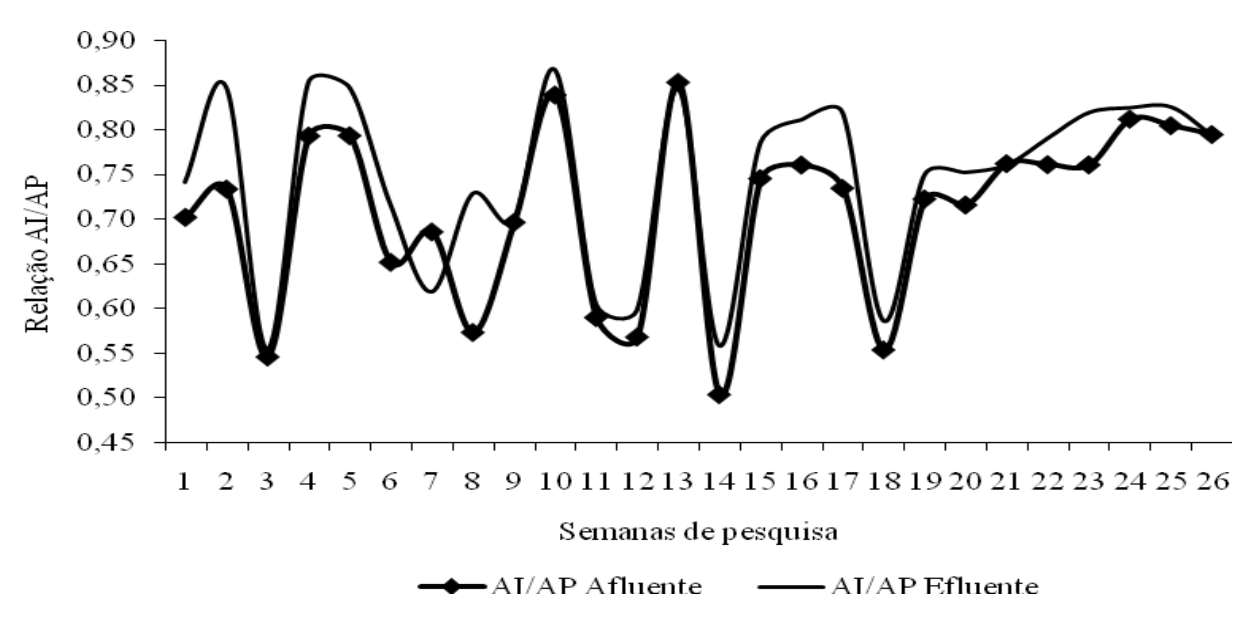

Figura 8. Comportamento da relação AI/AP no afluente e efluente do reator UASB.

\section{CONCLUSÃO}

O reator UASB operou com cargas orgânicas volumétricas máximas de 59,0 kgDQO m $\mathrm{d}^{-1}$, sem contudo ultrapassar o limite na concentração de ácidos voláteis demonstrando suportar altas cargas sem prejudicar a microbiota do reator.

A caracterização morfológica do lodo do reator UASB, realizada por meio da microscopia eletrônica de varredura (MEV), indicou que o comportamento do $\mathrm{pH}$, acidez e alcalinidade não influenciaram negativamente no processo microbiológico, mesmo quando as relações AI/AP foram maiores que 0,3 como estabelecido por Ruipley et al. (1986).

Para estimativas e estudos das atividades microbiológicas, a temperatura tem um importante significado, pois demonstra ter influência direta sobre a biomassa. A presente pesquisa concluiu que mesmo que termos-higrômetro sejam mais práticos em experimentos de campo, para melhores resultados é necessário a adoção de temperaturas do lodo.

Observou-se ainda que os parâmetros adotados na pesquisa evitaram choques orgânicos e hidráulicos e possibilitaram a manutenção do tamponamento, permitindo condições adequadas à floculação e à granulação da biomassa no reator UASB.

\section{AGRADECIMENTOS}

Os autores agradecem ao Laboratório de Análises de Água do Departamento de Engenharia (LAADEG/UFLA) pela execução das análises. À FAPEMIG pelo apoio financeiro das instalações e equipamentos do sistema piloto de tratamento, por meio do Projeto TEC 1550/03.

\section{REFERÊNCIAS BIBLIOGRÁFICAS}

CAMPOS, C. M. M.; SALÉH, B. B.; CARMO, F. R. Determination of kinetic parameters of a lab-scale upflow anaerobic sludge blanket reator (UASB) removing organic loading from swine manure effluents. Revista Ciência e Agrotecnologia, v. 29, p. 1045-1051, 2005a. 
CAMPOS, C. M. M.; DAMASCENO, L. H. S.; MOCHIZUKI, E. T.; BOTELHO, C. G. Performance evaluation of a lab-scale upflow anaerobic sludge blanket reactor (UASB) removing organic loading rate from swine manure. Revista Ciência e Agrotecnologia, v. 29, p. 848-856, 2005b.

CAMPOS, C. M. M.; MOCHIZUKI, E. T.; DAMASCENO, L. H. S.; CLÁUDIO GOUVÊA BOTELHO, C. G. Avaliação do potencial de produção de biogás e da eficiência de tratamento do reator anaeróbio de manta de lodo (UASB) alimentado com dejetos de suínos. Revista Ciência e Agrotecnologia, v. 29, p. 848-856, 2005c.

CAMPOS, C. M. M.; CARMO, F. R. DO; BOTELHO, C. G.; COSTA, C. C. da, Development and operation of an upflow anaerobic sludge blanket reactor (UASB) treating liquid effluent from swine manure in laboratory scale. Revista Ciência e Agrotecnologia, v. 30, p. 140-147, 2006.

CHERNICHARO, C. A. L. Reatores anaeróbios: princípios do tratamento biológico de águas residuárias. Belo Horizonte: Politécnica, 2007. 379 p.

COSTA, C. C. Avaliação de sistema anaeróbio (RAC-UASB) no tratamento de água residuária de suinocultura e aplicação via fertirrigação, em feijão-vagem cultivado em ambiente protegido. 2007. 173f. Tese (Doutorado em Engenharia de Água e Solo) - Universidade Federal de Lavras, Lavras, 2007.

FERNANDES, G. F. R.; OLIVEIRA, R. A. Desempenho de processo anaeróbio em dois estágios (reator compartimentado seguido de reator UASB) para tratamento de águas residuárias de suinocultura. Engenharia Agrícola, v. 26, n. 1, p. 243-256, 2006.

GRADY, C. P. L. Jr. LIM, H. C. Biological Waste Treatment. New York: Marcel Dekker, 1980.

KUS, F.; WIESMANN, U. Degradation kinetics of acetate and propionate by immobilized anaerobic mixed cultures. Water Research, New York, v. 29, n. 29, n. 6, p. 1437-43, 1995.

LOURENÇO, A. P. M.; CAMPOS, C. M. M. Hydrodynamic behavior of a lab-scale upflow anaerobic sludge blanket reactor (UASB) operated with an adopted hydraulic retention time (HRT) of 12 hours. Revista Ciência e Agrotecnologia, Lavras, v. 33, n. 4, p. 1139-1144, jul./ago. 2009.

METCALF \& EDDY. Wastewater engineering: treatment, disposal and reuse. 4. ed. New York: McGraw - Hill, 2003.

NEVES, L. Caracterização de biomassa anaeróbia granular: análise qualitativa e quantitativa de imagem, hibridização com sondas genéticas (FISH) e técnicas histológicas. 2004. 217f. Dissertação (Mestrado em Tecnologia do Ambiente) Universidade do Minho, Braga, 2004.

OLIVEIRA, R. A. de; VAZOLLER, R. F.; FORESTI, E. Sludge bed characteristics of UASB reactors: growth, activity, microbial structure and chemical composition of granules. In: INTERNATIONAL CONFERENCE ON ANAEROBIC DIGESTION, 8, 1997, Sendai, Japan. Proceedings... Sendai: IAWQ, 1997. p. 524-531.

RIPPLEY, L. E.; BOYLE, W. C.; CONVERSE, J. C. Improved alkalimetric monitoring for anaerobic digestion of high-strength wastes. Journal Water Pollution Control Federation, Alexandria, v. 58, n. 5, p. 406-411, 1986. 
PEREIRA, E. L.; CAMPOS, C. M. M.; MOTERANI, F. Efeitos do pH, acidez e alcalinidade na microbiota de um reator anaeróbio de manta de lodo (UASB) tratando efluentes de suinocultura. Ambi-Agua, Taubaté, v. 4, n. 3, p. 157-168, 2009. (doi:10.4136/ambi-agua.109)

SANTANA, A. M. de.; OLIVEIRA, R. A. de. Desempenho de reatores anaeróbios de fluxo ascendente com manta de lodo em dois estágios tratando água residuárias de suinocultura. Engenharia Agrícola, Jaboticabal, v. 25, n. 3, p. 817-830, 2005.

STEIL, L.; LUCAS JUNIOR, J.; OLIVEIRA, R. A. Avaliação do uso de inóculos na digestão anaeróbia de resíduos de aves de postura, frango de corte e suínos. Engenharia Agrícola, Jaboticabal, v. 22, n. 2, p. 146-159, 2002.

ZEGERS, F. Anaerobic treatment of the wine drawn. In: Universidad del Valle; Corporacion Autonoma Regional del Cauca; Universidad Agricola de Wageningen. Arranque y Operacion de Sistemas de Flujo Ascendente con Manto de Lodo (UASB). Manual del Curso. [S.l]: [S.n.], nov. 1987. 